\title{
Dihydropyridine Actions on Calcium Currents of Frog Sympathetic Neurons
}

\author{
Stephen W. Jones and Leila S. Jacobs \\ Department of Physiology and Biophysics, Case Western Reserve University, Cleveland, Ohio 44106
}

\begin{abstract}
Dihydropyridines (DHPs) generally have little effect on wholecell calcium currents of neurons, even at concentrations far higher than those effective on muscle. Either neuronal calcium currents are much less sensitive to DHPs, or only a small proportion of the current is DHP-sensitive. We find that DHP agonists and antagonists act at low concentration on calcium currents in frog sympathetic neurons but that the effects are small even at optimal concentrations. The halfmaximal dose $\left(E_{50}\right)$ of the agonist Bay K 8644 is $\sim 50 \mathrm{nM}$, and the effect of Bay K 8644 is blocked by $50 \%$ at $\sim 300 \mathrm{nM}$ nifedipine, from a holding potential of $-80 \mathrm{mV}$. Nifedipine is more effective from a holding potential of $-50 \mathrm{mV}$. These results suggest the presence of an L-type calcium current, with DHP sensitivity similar to L-currents in cardiac muscle. The predominant $(>90 \%)$ calcium current in frog sympathetic neurons is a DHP-resistant $\mathrm{N}$-type current. However, high concentrations of DHPs $(10 \mu \mathrm{M})$ partially block N-type calcium current, as well as voltage-dependent sodium and potassium currents.
\end{abstract}

Calcium currents are necessary for a wide variety of cellular functions, ranging from muscle contraction to neurotransmitter release. The time scale of these processes varies from hundreds to tenths of milliseconds. It is perhaps not surprising that a variety of calcium channels would evolve to serve these diverse functions. The proposal (Nowycky et al., 1985) of a novel (Ntype) calcium current, specialized for the extremely rapid process of transmitter release from neurons (Perney et al., 1986; Hirning et al., 1988), thus received wide initial acceptance. However, the $\mathrm{N}$-current cannot be easily separated from the classic L-current in whole-cell recordings, so some have questioned the existence of 2 distinct currents (Swandulla and Armstrong, 1988).

At the single-channel level, it appears clear that both L- and $\mathrm{N}$-type channels exist in sympathetic neurons (Hirning et al., 1988; Lipscombe et al., 1988). Recently, Jones and Marks (1989a, b) and Plummer et al. (1989) proposed that the whole-cell current is primarily N-type but that dihydropyridine (DHP) agonists reveal a cryptic L-current. With this interpretation, the $\mathrm{N}$-current of sympathetic neurons differs from that originally described in sensory neurons (Fox et al., 1987a, b) in showing

Received Dec. 18, 1989; revised Feb. 7, 1990; accepted Feb. 13, 1990.

This work was supported by National Institutes of Health Grant NS 24471 to S.W.J., and I.S.J. was supported by training grant HL 07653. We thank Theodore N. Marks and Dr. Keith S. Elmslie for helpful comments on the manuscript. We also thank Drs. A. Scriabine, D. Roemer, and E. Rissi for providing samples of DHPs.

Correspondence should be addressed to Stephen W. Jones at the above address.

Copyright (C) 1990 Society for Neuroscience $0270-6474 / 90 / 072261-07 \$ 03.00 / 0$ slow $(\tau \sim 200 \mathrm{msec})$ and incomplete inactivation. Thus, the kinetics of whole-cell calcium currents do not readily distinguish $\mathrm{L}$ - and N-currents. In particular, the current remaining at the end of $a \sim 1$ sec depolarization cannot be identified as L-current (Aosaki and Kasai, 1989; Bean, 1989; Jones and Marks, 1989b; Plummer et al., 1989; see also Tsien et al., 1988).

The actions of DHPs thus become critical for distinguishing these otherwise similar currents. In whole-cell recordings, the clearest evidence for the existence of the L-current is a slight potentiation by DHP agonists, most obvious in slow tail currents (Jones and Marks, 1989a; Plummer et al., 1989). However, the definition of the L-current as a current potentiated by DHP agonists (Plummer et al., 1989) obviously begs the question of the contribution of the L-current under normal conditions. The use of DHP antagonists is problematic, as their action is strongly voltage dependent (Bean, 1984; Sanguinetti and Kass, 1984).

This paper demonstrates that the neuronal L-current is similar in DHP sensitivity to the predominant (L-type) calcium current of cardiac muscle. This supports the qualitative distinction between DHP-resistant N-current and highly DHP-sensitive L-current. However, extremely high concentrations of DHPs $(\sim 10 \mu \mathrm{M})$ have nonspecific blocking actions on other voltagedependent currents. These results also support previous conclusions that the L-current contributes little $(<10 \%)$ to wholecell calcium currents in sympathetic neurons (Jones and Marks, 1989a; Plummer et al., 1989).

A preliminary report of some of these results has appeared (Jones and Jacobs, 1989).

\section{Materials and Methods}

Currents were recorded in the whole-cell patch-clamp configuration using an Axopatch 2A amplifier (Axon Instruments, Burlingame, CA) from isolated frog sympathetic neurons (Jones and Marks, 1989a). Bullfrogs (Rana catesbeiana) were used for most experiments, but Rana pipiens were occasionally substituted. For experiments on calcium currents, electrodes contained $76.5 \mathrm{mM} N$-methyl-D-glucamine (NMG) chloride, $2.5 \mathrm{~mm}$ HEPES, $10 \mathrm{~mm}$ EGTA or BAPTA, $5 \mathrm{~mm}$ Tris ATP, and $4 \mathrm{mM} \mathrm{MgCl}_{2}$, titrated to $\mathrm{pH} 7.2$ with NMG base; the extracellular solution was $117.5 \mathrm{mM} \mathrm{NMG} \cdot \mathrm{Cl}, 2.5 \mathrm{~mm} \mathrm{NMG} \cdot \mathrm{HEPES}$, and $2 \mathrm{~mm}$

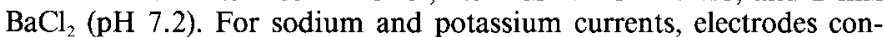
tained $100 \mathrm{~mm} \mathrm{KCl}, 2.5 \mathrm{~mm}$ NaHEPES, $4 \mathrm{~mm} \mathrm{MgCl}_{2}, 5 \mathrm{~mm} \mathrm{Na}_{2} \mathrm{ATP}$, and $1 \mathrm{mM} \mathrm{K}_{2}$ EGTA, titrated to $\mathrm{pH} 7.2$ with $\mathrm{KOH}$; the extracellular solution was $115 \mathrm{~mm} \mathrm{NaCl}, 2.5 \mathrm{~mm} \mathrm{KCl}, 2.5 \mathrm{~mm} \mathrm{NaHEPES}$, and 2 $\mathrm{mM} \mathrm{MnCl}_{2}$ (pH 7.2).

Bay K 8644 and nifedipine were obtained from Calbiochem (La Jolla, CA) or Dr. A. Scriabine (Miles Institute, West Haven, CT); $\omega$-conotoxin from Peninsula Laboratories (Belmont, CA); $(+) 202-791$ and (-)202791 from Drs. D. Roemer and E. Rissi (Sandoz, Basel, Switzerland); ATP, NMG, EGTA, BAPTA, and HEPES from Sigma (St. Louis, MO). Other chemicals were reagent grade. Drugs were applied by superfusion in a $\sim 1 \mathrm{ml}$ bath, with flow controlled remotely by solenoid valves.

Compensation for series resistances of $2-4 \mathrm{M} \Omega$ was $80 \%$, giving ex- 


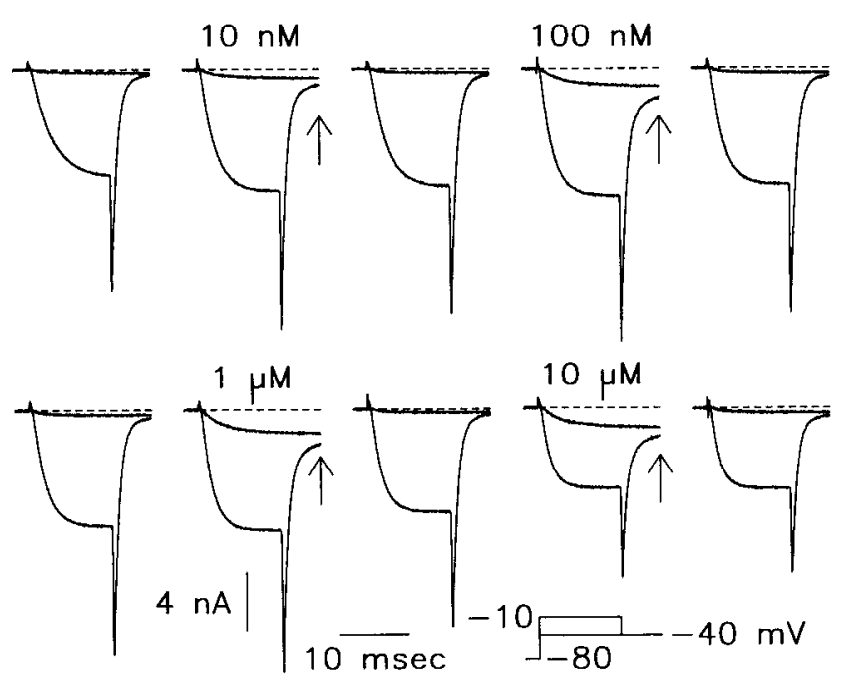

Figure 1. Effects of various concentrations of Bay K 8644 on calcium currents. Each record shows 2 superimposed sweeps, for a step directly to $-40 \mathrm{mV}$ and for a step to $-10 \mathrm{mV}$ followed by partial repolarization to $-40 \mathrm{mV}$, from the holding potential of $-80 \mathrm{mV}$ (see illustration of voltage protocol at lower right). Records were taken sequentially from the initial control (upper left) to the final recovery (lower right). Each concentration of Bay K 8644 was applied by bath superfusion, with return to control solution following each application, so that control records alternate with records of currents in Bay K 8644. Arrows indicate the slow tail currents in Bay K 8644. The activation kinetics speed up with time during this long $(\sim 2 \mathrm{hr})$ recording, probably due to a slow shift in the voltage dependence of the currents to more negative potentials. Some drift in the amplitude of the peak current (an initial increase followed by rundown) is also evident. Cell 89208.

pected voltage errors of $0.4-0.8 \mathrm{mV} / \mathrm{nA}$. Data were digitized at $70-100$ $\mathrm{kHz}$. following $20 \mathrm{kHz}$ analog filtering, except for experiments on the M-type and A-type potassium currents ( $2 \mathrm{kHz}$ after $500 \mathrm{~Hz}$ filtering). pCLAMP (Axon Instruments) was used to control the experiment, and pCLAMP, 1-2-3 (Lotus, Cambridge, MA), and Windows Draw (Micrografx, Richardson, TX) were used to analyze and display data. Data were leak subtracted using scaled and averaged currents from hyperpolarizing voltage steps and digitally filtered at $3-4 \mathrm{kHz}$ or as noted. The holding potential was $-80 \mathrm{mV}$ unless otherwise noted.

\section{Results}

\section{Agonists}

The DHP calcium channel agonist Bay K 8644 has little effect on the peak calcium current but markedly enhances the current at negative membrane potentials (Fig. 1). This is apparent as an increase in current upon depolarizing steps directly to -40 $\mathrm{mV}$, which under control conditions elicit a barely detectable current. In addition, a slow component appears in tail currents following repolarization to $-40 \mathrm{mV}$ from more depolarized voltages (Fig. 1, arrows). The effect of Bay K 8644 is dosedependent and slowly reversible (Fig. $2 A$ ).

High concentrations of Bay K 8644 actually decrease the peak calcium current (Fig. $2 A$ ), which could be due to a partial antagonist action (Sanguinetti et al., 1986). Bay K 8644 contains 2 isomers, one of which is actually an antagonist (Kass, 1987). However, the inhibitory effect is also seen with the "pure" DHP agonist isomer $(+) 202-791$ (Fig. $2 B$ ). Note particularly that the first application of $10 \mu \mathrm{M}(+) 202-791$ had a complex effect on the peak current. Much later in the same cell, $10 \mu \mathrm{M}(+) 202-$ 791 had a much smaller effect on the slow tail currents, suggesting that most of the DHP agonist-sensitive current had run down. The effect on peak current was then a monophasic in-
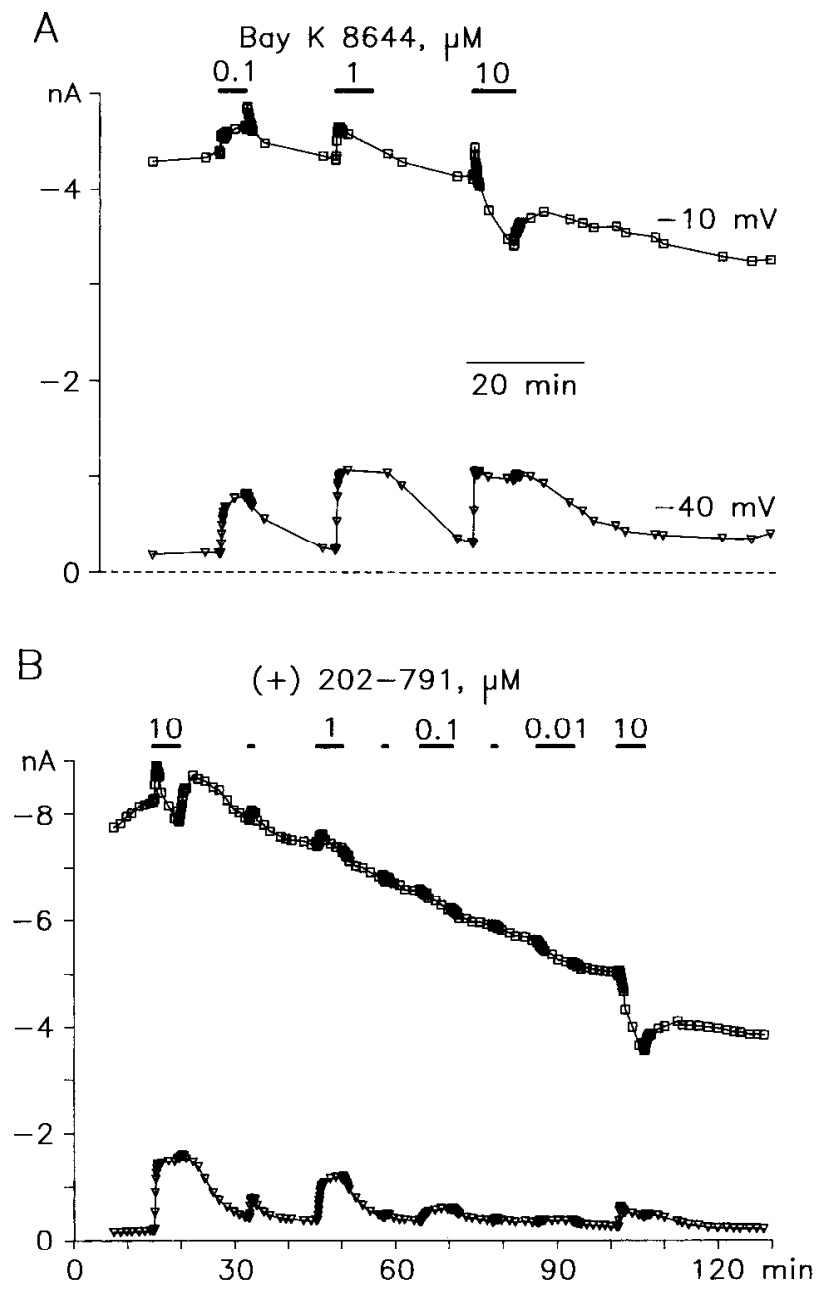

Figure 2. Time course of DHP agonist effects. A, Horizontal bars mark the duration of application of Bay $\mathrm{K} 8644$. Currents were measured every $5 \mathrm{sec}$ during washin and washout of Bay K 8644, and less frequently otherwise. Increasing current is shown upwards. The peak current at $-10 \mathrm{mV}(\square)$ and the tail current at 5-6 msec following repolarization from -10 to $-40 \mathrm{mV}(\nabla)$ were measured. The "tail current" measurement includes both the steady-state current at $-40 \mathrm{mV}$ and any slowly deactivating tail current (see Fig. 1). Cell 88d29. B, Effect of $(+) 202-791$, measured as for Bay K 8644, for concentrations in decreasing order, with the highest concentration applied again at the end of the experiment. The shorter horizontal bars mark points where control solution was washed through the flow system to remove any drug remaining in the tubing. Cell a9928.

hibition. It appears likely that the complex effect observed during the first application is a superposition of a slowly developing but rapidly reversible inhibition, and a rapidly developing but slowly reversible potentiation. This sequence of effects was observed in 2 other cells where $10 \mu \mathrm{M}(+) 202-791$ was tested more than once. One explanation of this result is that the inhibition and the potentiation are of different currents, which run down at different rates.

The activation kinetics of currents near $0 \mathrm{mV}$ and the major rapid component of tail current at $-40 \mathrm{mV}$ appear unaffected by Bay K 8644 (Fig. 1). The most sensitive measure of enhancement of calcium current by DHP agonists is the tail current 5-6 msec following repolarization to $-40 \mathrm{mV}$, where the fast component was essentially complete but the slow component 


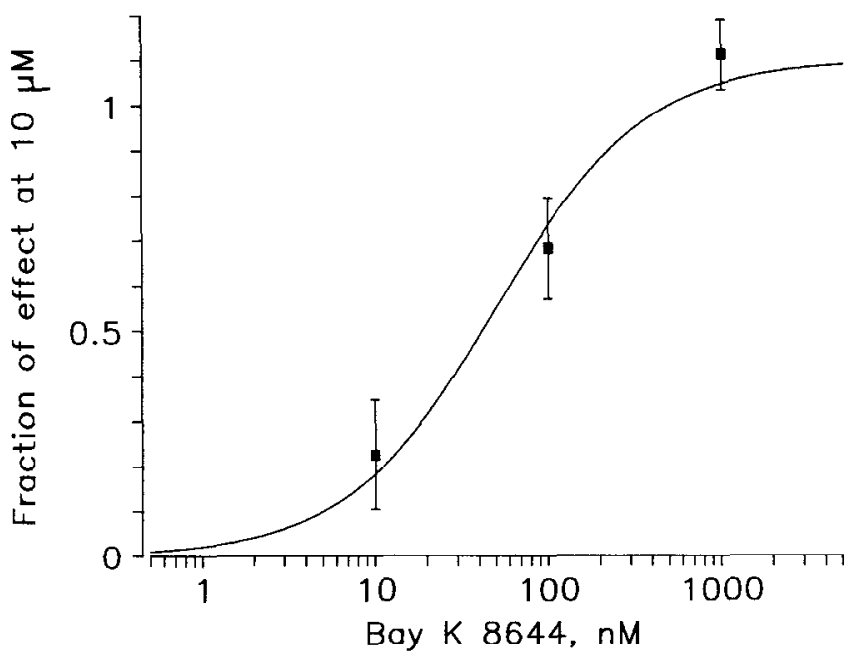

Figure 3. Dose-response relations for Bay $\mathrm{K} 8644$. The increase in tail currents at $-40 \mathrm{mV}, 5-6 \mathrm{msec}$ following repolarization from -10 or $0 \mathrm{mV}$, was measured. To correct for rundown, each measurement was divided by the amplitude of the peak current prior to that application of Bay K 8644. As the maximal effect of Bay K 8644 varied from cell to cell (5- to 15-fold enhancement of the slow tail current), values were further normalized to that at $10 \mu \mathrm{M}$. Data are from 3 cells where all 4 concentrations were tested, plus 1 cell tested only at $0.1-10 \mu \mathrm{M}$. Data are means \pm SEM. The smooth curve is drawn from the law of mass action with maximal effect 1.1 times that at $10 \mu \mathrm{M}$, with a halfmaximal effect at $50 \mathrm{nM}$.

was still largely present (Plummer et al., 1989). That current could be increased severalfold by Bay K 8644 (Fig. 2A).

The effect of Bay K 8644 on tail currents was usually apparent at $10 \mathrm{~nm}$ (Figs. 1, 2A) and was maximal at $1-10 \mu \mathrm{M}$. Doseresponse relations (Fig. 3) indicate a half-maximal effect at $\sim 50$ nM. Since the effect of Bay K 8644 is voltage-dependent (Sanguinetti et al., 1986), the half-maximal effect might be different at other voltages. The shift of activation to more negative membrane potentials is reminiscent of Bay K 8644 effects on calcium currents of cardiac (Hess et al., 1984) and smooth muscle (Bean et al., 1986; Caffrey et al., 1986). However, the relative insensitivity of peak current to Bay K 8644 (Figs. 1,2) contrasts with the severalfold enhancement observed in muscle. The simplest

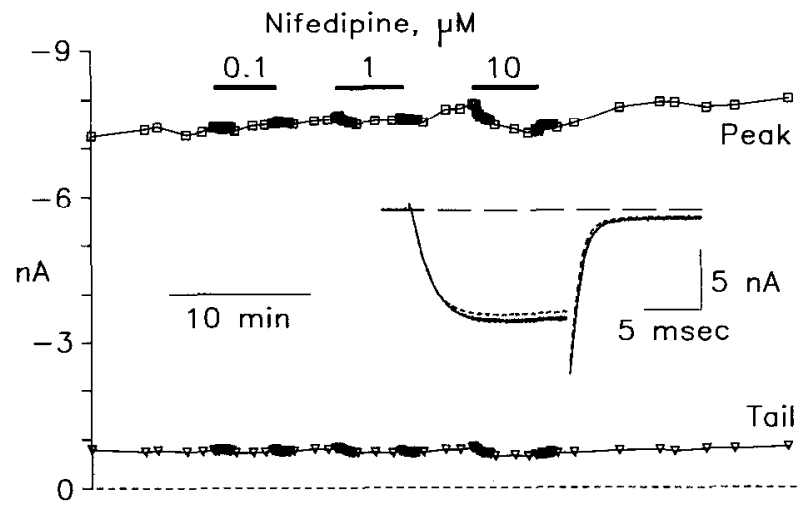

Figure 4. Effects of nifedipine on calcium current. The time course of effects on peak current at $-10 \mathrm{mV}$, and on slow tail currents, were measured as in Figure 2, except that tail currents were measured at -30 $\mathrm{mV}$. Inset, Superimposed currents recorded before, during (short dashed. lines), and after $10 \mu \mathrm{M}$ nifedipine, with $300 \mu \mathrm{sec}$ blanked at the start and end of each voltage step. Cell d 9726.
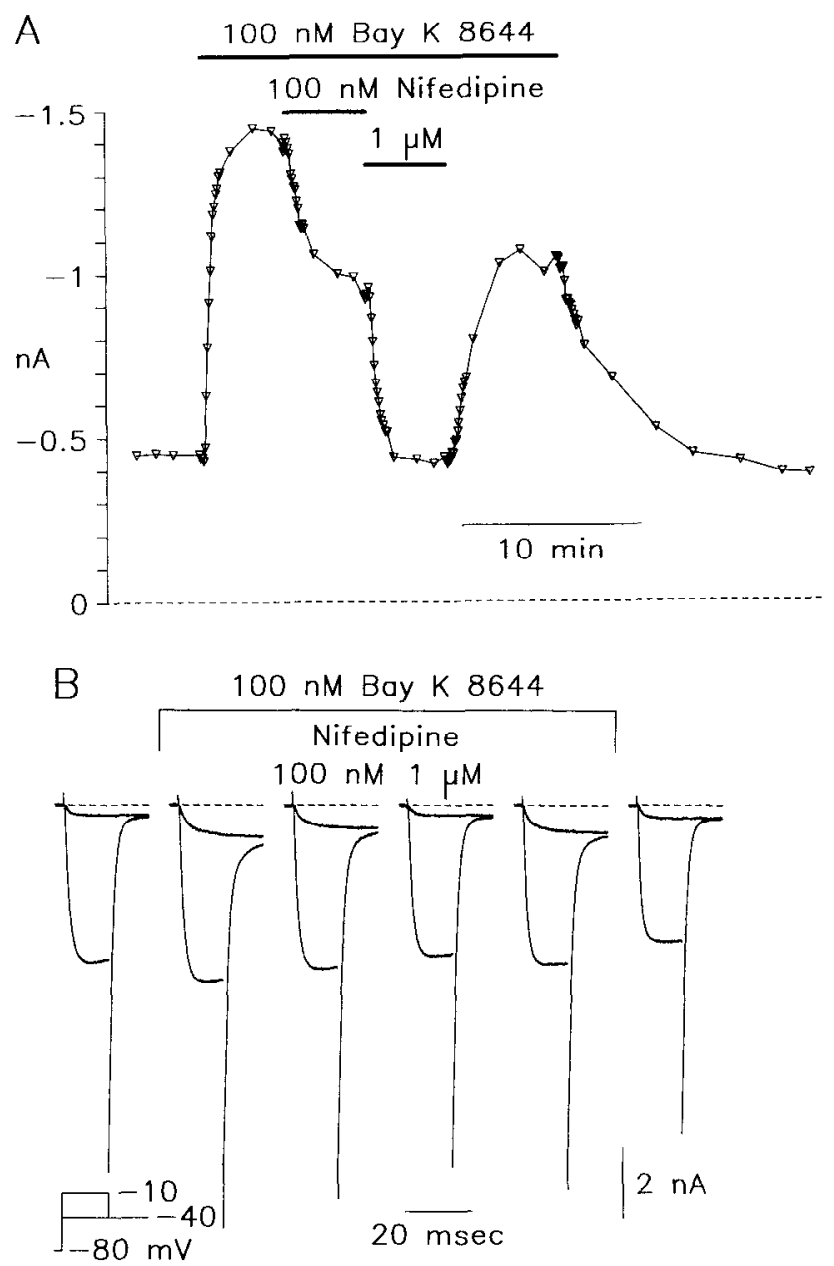

Figure 5. Nifedipine blocks the effect of Bay K 8644. A, Time course of Bay K 8644 and nifedipine action on slow tail currents, measured as in Figure 2. Note that $100 \mathrm{~nm}$ Bay K 8644 was continuously present during additions of nifedipine. $B$. Records of currents from the same experiment (cell 89813). $300 \mu \mathrm{sec}$ were blanked.

explanation of these results is that Bay K 8644 acts with high potency on a neuronal calcium current, but only a small fraction of the total current is enhanced by DHP agonists.

\section{Antagonists}

If the current sensitive to DHP agonists is truly an L-current, it should be blocked by DHP antagonists, in a voltage-dependent manner. The small maximal effect of DHP antagonists on the control current (Jones and Marks, 1989a; Plummer et al., 1989) makes it difficult to examine their potency directly (Fig. 4). But the current potentiated by DHP agonists is large enough for blockade by DHP antagonists to be studied (Fig. 5). In the cell illustrated in Figure 5, nifedipine reversibly inhibited the effect of Bay K 8644. At $100 \mathrm{nM}$, nifedipine had a clear effect, and at $1 \mu \mathrm{M}$ reduced the slow tail currents essentially to control levels. Preliminary experiments indicate that other DHP antagonists [nimodipine, nisoldipine, and (-)202-791] have effects qualitatively similar to nifedipine, but the effect of nifedipine appears to be most readily reversible. Dose-response relations for 9 cells (each tested at 2 nifedipine concentrations, as in Fig. $5 \mathrm{~A}$ ) are shown in Figure 6 (solid symbols and line). The DHP agonistenhanced current of frog sympathetic neurons is clearly sensitive 


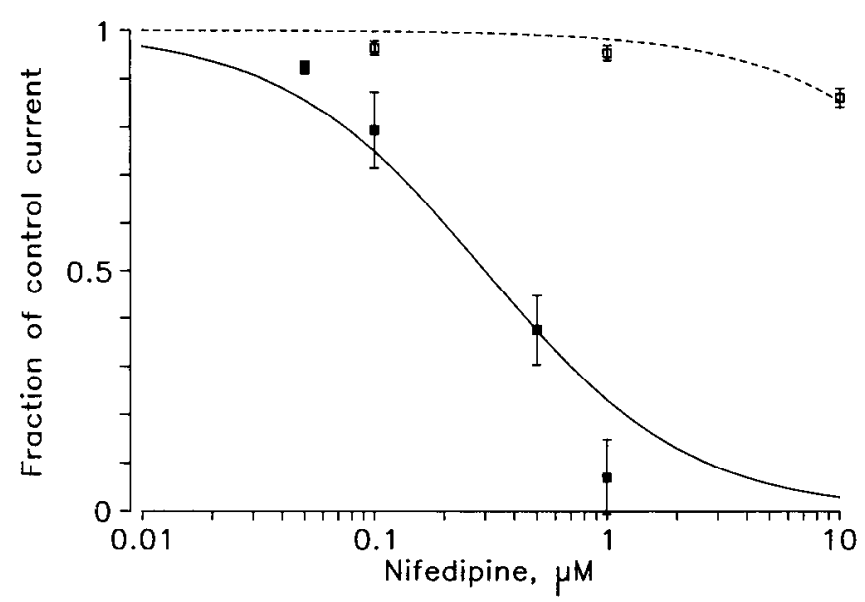

Figure 6. Dose-response relations for nifedipine. Data, from the protocol of Figure $5 \mathrm{~A}$, are normalized such that 0 equals the average of tail currents before and after Bay K 8644, and 1 equals the average of tail currents in Bay K 8644 before and after nifedipine ( $\square$ ). Five cells were tested at 100 and $1000 \mathrm{~nm}$ nifedipine, and 4 cells at 50 and $500 \mathrm{~nm}$. The solid curve is drawn from the law of mass action, fit by eye to an $\mathrm{EC}_{50}$ of $300 \mathrm{nM}$. The effect of nifedipine on the peak current (in the absence of Bay $\mathrm{K}$ 8644) is also shown ( $\square$ ), for 4-5 cells at each concentration. The dashed line is drawn for an $\mathrm{EC}_{50}$ of $30 \mu \mathrm{M}$.

to nifedipine at $<1 \mu \mathrm{M}$, even from a holding potential of -80 $\mathrm{mV}$, with an $\mathrm{EC}_{50}$ of $\sim 300 \mathrm{nM}$. Nifedipine is much less effective on the control currents in the absence of agonist (Fig. 6, open symbols), with a small but detectable block at $10 \mu \mathrm{M}$ (13.6 \pm $1.9 \%$, mean \pm SEM, $n=5$; compared to $4.4 \pm 1.4 \%, n=5$, at $1 \mu \mathrm{M})$.

Effects of nifedipine at more depolarized holding potentials are difficult to examine because of slow inactivation and rundown, but qualitatively it appears to be more potent (Fig. 7). Nifedipine at 50-100 nм blocked $\sim 50 \%$ of the slow agonistinduced tail current in cells held continuously for several minutes at $-50 \mathrm{mV}$ in 3 of 3 cells, but recovery was incomplete.

In most cells, it has been possible to detect an effect of 100 nM nifedipine on currents without Bay K 8644, when the $\mathrm{N}$-current is selectively reduced by pretreatment with $\omega$-conotoxin (see Plummer et al., 1989). In the cell shown in Figure 8, $100 \mathrm{~nm}$ nifedipine blocked $\sim 50 \%$ of the current from a holding potential of $-50 \mathrm{mV}$, but only $\sim 20 \%$ from $-80 \mathrm{mV}$. The difference may be partially due to rundown, however, as a subsequent test at $-50 \mathrm{mV}$ produced little effect (Fig. $8 A$ ). If any residual $\mathrm{N}$-current is present, at least $50 \%$ of the L-current must have been blocked by $100 \mathrm{nM}$ nifedipine from the holding potential of $-50 \mathrm{mV}$. On average, $100 \mathrm{~mm}$ nifedipine blocked 36 $\pm 7 \%(n=4)$ of the total current remaining after $\omega$-conotoxin from a holding potential of $-50 \mathrm{mV}$, and $13 \pm 3 \%(n=7)$ from $-80 \mathrm{mV}$. Most of the $\omega$-conotoxin-resistant current, from a holding potential of $-80 \mathrm{mV}$, is also DHP-resistant $(20 \pm 7 \%$ block by $10 \mu \mathrm{M}$ nifedipine, $n=3$ ). The current blocked by nifedipine shows no clear differences in activation kinetics from the control current (Fig. 8B).

\section{Potassium and sodium currents}

The evidence for nonspecific effects of DHPs on N-current (Figs. $2,4)$ led us to investigate whether DHPs inhibit other voltagedependent currents. Figure $9 A$ shows that $10 \mu \mathrm{M}$ nifedipine has a substantial effect on the delayed rectifier potassium current
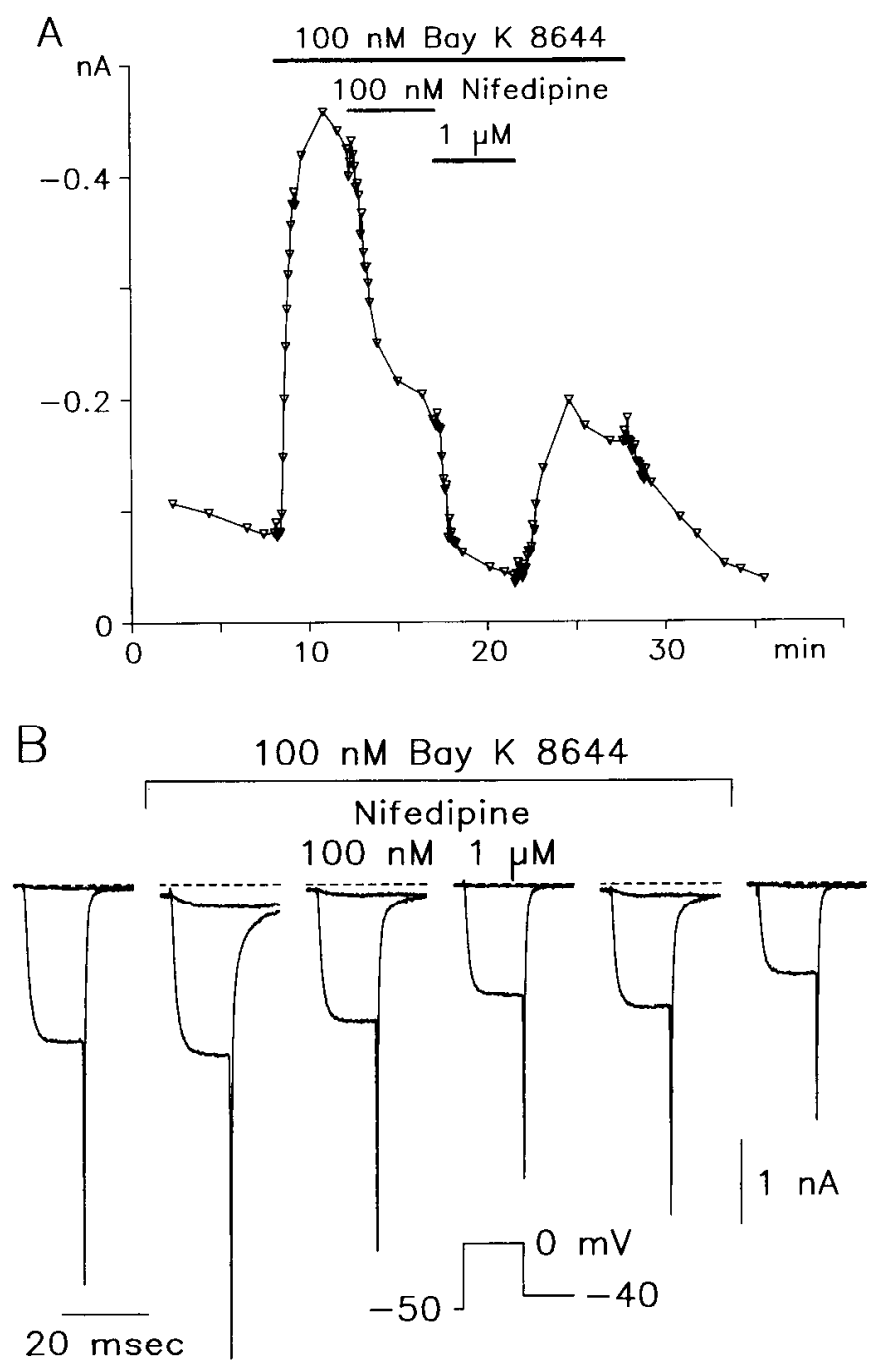

Figure 7. Effect of Bay K 8644 and nifedipine at a depolarized holding potential. $A$, Amplitude of slow tail currents at $-40 \mathrm{mV}$, from a holding potential of $-50 \mathrm{mV} . B$, Records of currents upon voltage steps from -50 to $0 \mathrm{mV}$, with tail currents at $-40 \mathrm{mV}$, from the same experiment. Note that Bay K 8644 caused an inward shift in the holding current at $-50 \mathrm{mV}$. Cell c9726.

$\left(I_{\mathrm{K}}\right)$ and a smaller effect on the sodium current. A different protocol (Fig. $9 \mathrm{~B}, \mathrm{C}$ ) demonstrates effects on 2 other potassium currents (Adams et al., 1982), the transient outward current $\left(I_{\mathrm{A}}\right)$ and the M-current $\left(I_{\mathrm{M}}\right)$. The rate of inactivation of $I_{\mathrm{A}}$ also appeared to be increased by nifedipine. These effects were concentration-dependent, as less block was observed at $1 \mu \mathrm{M} \mathrm{ni-}$ fedipine (Table 1). Consistent with a nonspecific action of DHPs, the agonist $(+) 202-791$ also reduced the amplitude of these 4 currents at $10 \mu \mathrm{M}$ (Table 1). The effect of $(+) 202-791$ was consistently slower than that of nifedipine and did not always reach a steady-state during the $\sim 5 \mathrm{~min}$ applications used, so its potency on sodium and potassium currents may be underestimated here.

\section{Discussion}

The DHP-sensitive current of frog sympathetic neurons is similar in sensitivity to both DHP agonists and antagonists to the DHP-sensitive (L-type) current of cardiac muscle. This supports the previous assumption that the relative DHP insensitivity of 

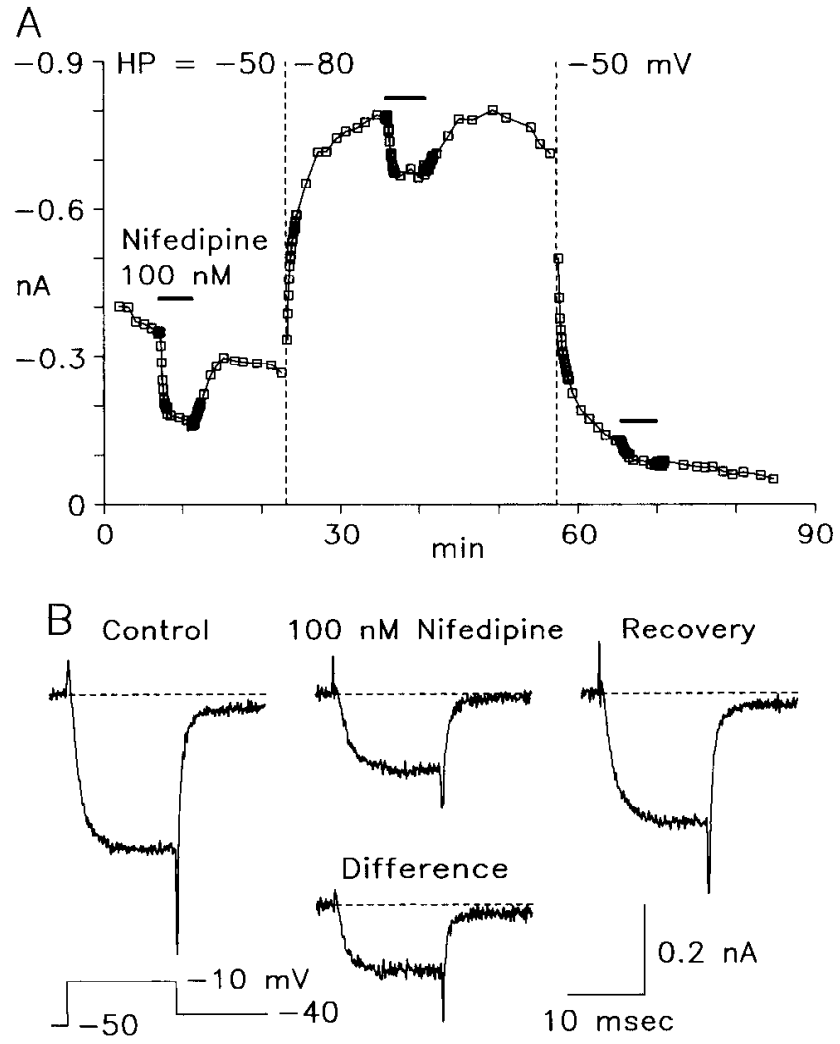

Figure 8. Effects of nifedipine on currents not potentiated by Bay $\mathrm{K}$ 8644. This cell (e9830) had been pretreated with $\omega$-conotoxin for 10 min before recording was begun. The current amplitudes in $\omega$-conotoxin-pretreated cells were generally consistent with the previously reported $\sim 85 \%$ block of the total calcium current by $\omega$-conotoxin (Jones and Marks, 1989a). $A$, Peak currents at $-10 \mathrm{mV}$ (口). The holding potential was changed from -50 to $-80 \mathrm{mV}$ at the times indicated. Zero time is the start of whole-cell recording. $B$, Records from the same experiment, taken before (left), during (middle), and after (right) the first response to nifedipine from $-50 \mathrm{mV}$. The current blocked by nifedipine (difference current, calculated as the average of control and recovery records minus the current remaining in nifedipine) is shown below. The fast component of the tail currents is reduced by filtering $(2 \mathrm{kHz})$.

neuronal calcium currents is due to the presence of qualitatively different currents rather than to a quantitatively lower potency on neuronal DHP-sensitive currents. DHP-sensitive calcium channels exist in frog sympathetic neurons (Lipscombe et al., 1988) but contribute little whole-cell current in the absence of DHP agonists, so the DHP-resistant $\mathrm{N}$-current dominates.

Most previous studies on neuronal calcium currents have used high $(>1 \mu \mathrm{M})$ concentrations of DHP agonists and antagonists, which raised the possibility that neuronal DHP-sensitive calcium channels were less sensitive to DHPs than are calcium channels in muscle (McCleskey et al., 1986; Taylor, 1988). That appears not to be the case. The $\mathrm{EC}_{50}$ of $50 \mathrm{~nm}$ for Bay K 8644 agrees well with values reported previously for cardiac muscle

Figure 9. Effects of nifedipine on potassium and sodium currents. Calcium and calcium-dependent currents were blocked by $\mathrm{Mn}^{2+}$ (see Materials and Methods). $A$, Inhibition of delayed rectifier and sodium currents. Brief $(17 \mathrm{msec})$ depolarizations to $+10 \mathrm{mV}$ from a holding potential of $-50 \mathrm{mV}$ cvokc a rapid inward current followed by a slower outward current (inset). Three superimposed records are shown, taken before, during (dashed line) and after nifedipine, at the times marked
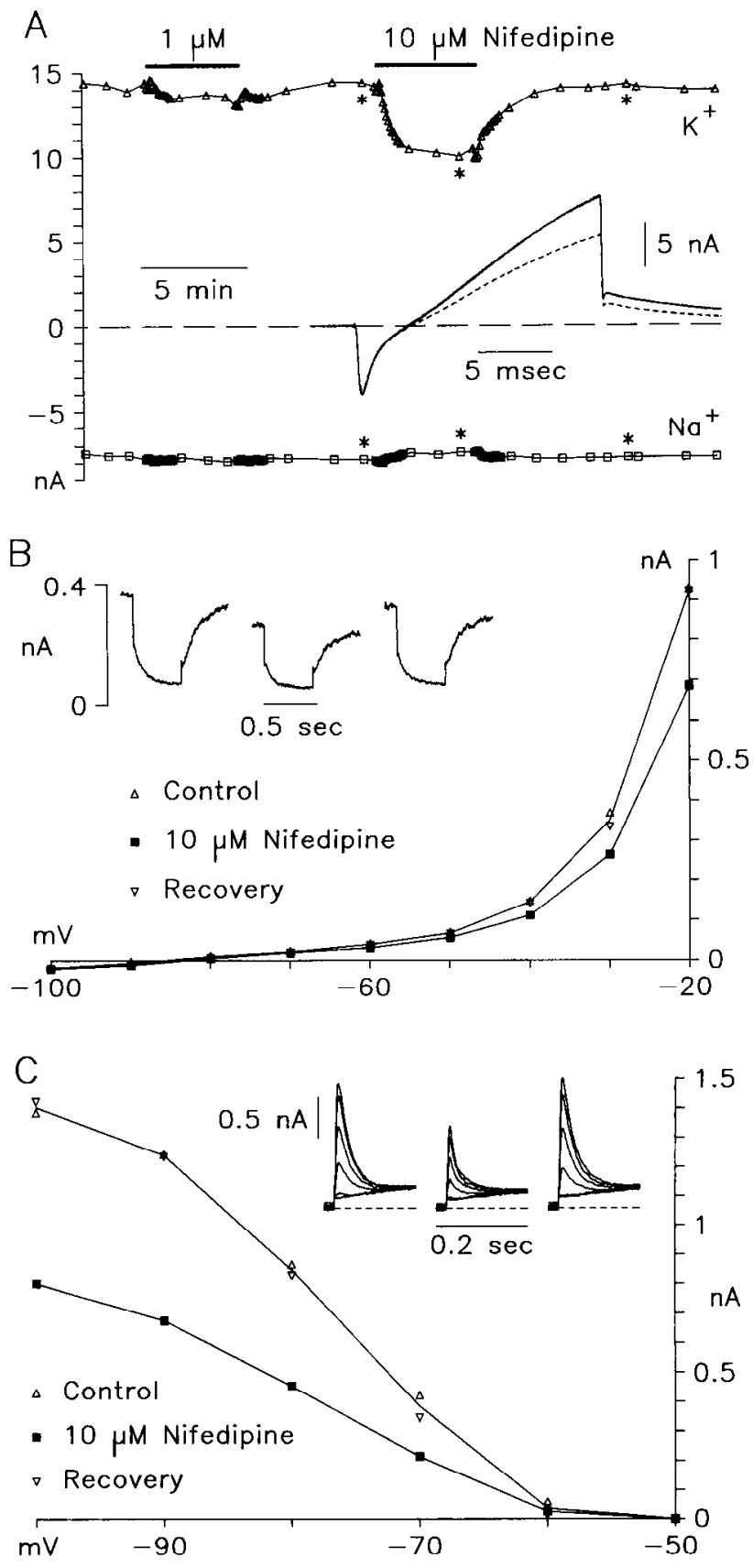

by asterisks in the main figure. The records were digitally filtered at 6 $\mathrm{kHz}$. The main figure shows the time course of the peak inward current $(\square)$ and the current at the end of the depolarization $(\triangle)$. Cell a9n11. $B$, Inhibition of $I_{\mathrm{M}}$. Voltage steps lasting $0.45 \mathrm{sec}$ were given from a holding potential of $-30 \mathrm{mV}$. The main figure shows the "steady-state" currentvoltage relations measured at the end of each voltage step. Currents were not leak-subtracted and are given with respect to zero current. Inset shows currents recorded (left to right) before, during, and after 10 $\mu \mathrm{M}$ nifedipine, upon voltage steps from -30 to $-50 \mathrm{mV}$. The records were digitally filtered at $100 \mathrm{~Hz}$. Cell a9n08. $C$, Inhibition of $I_{\mathrm{A}}$, from the same experiment as $B$. Following steps to voltages more negative than $-50 \mathrm{mV}$, a transient outward current was observed upon return to $-30 \mathrm{mV}$. The main figure shows the amplitude of the peak outward current at $-30 \mathrm{mV}$, measured $\sim 10 \mathrm{msec}$ after a $0.45 \mathrm{sec}$ step to the indicated voltage. This is effectively the steady-state inactivation curve for $I_{\mathrm{A}}$. The current measured after a step to $-50 \mathrm{mV}$ was defined as zero. Inset, Currents upon return to $-30 \mathrm{mV}$ from voltages between -50 and $-100 \mathrm{mV}$, in $10 \mathrm{mV}$ intervals. The currents were not leak subtracted and were digitally filtered at $200 \mathrm{~Hz}$. The dashed line indicates zero current. The slowly activating outward current, most obvious after steps that generate little $I_{\mathrm{A}}$, is $I_{\mathrm{M}}$. 
Table 1. Inhibition of potassium and sodium currents by dihydropyridines

\begin{tabular}{|c|c|c|c|c|c|}
\hline \multirow[b]{2}{*}{ Drug } & \multirow{2}{*}{$\begin{array}{l}\text { Con- } \\
\text { cen- } \\
\text { tra- } \\
\text { tion } \\
(\mu \mathrm{M})\end{array}$} & \multicolumn{4}{|c|}{$\%$ Inhibition } \\
\hline & & $I_{\mathrm{A}}$ & $I_{\mathrm{K}}$ & $I_{\mathrm{M}}$ & $I_{\mathrm{Na}}$ \\
\hline Nifedipine & 1 & $8 \pm 1$ & $9 \pm 2$ & $10 \pm 3$ & $1 \pm 2$ \\
\hline Nifedipine & 10 & $46 \pm 4$ & $36 \pm 4$ & $22 \pm 2$ & $12 \pm 3$ \\
\hline$(+) 202-791$ & 10 & $54 \pm 6$ & $37 \pm 1$ & $22 \pm 2$ & $30 \pm 4$ \\
\hline
\end{tabular}

Values are means \pm SEM for 3-4 cells. The average of measurements taken before and after each drug application was used as the control value, to correct for rundown or drift in current amplitudes. $I_{\mathrm{A}}$ was measured as the difference between currents at $-30 \mathrm{mV}$ following $0.45 \mathrm{sec}$ steps to -100 and $-60 \mathrm{mV}$ (see Fig. 9C). $I_{\mathrm{M}}$ was measured as the leak-subtracted steady-state current at $-30 \mathrm{mV}$. $I_{\mathrm{Na}}$ was measured as the peak inward current, and $I_{\mathrm{K}}$ at $17 \mathrm{msec}$, for steps to 0 or +10 $\mathrm{mV}$, after leak subtraction (see Fig. $9 A$ ). Separate experiments with saxitoxin and tetraethylammonium (not shown) indicate that the delayed rectifier activates with a 2-3 msec delay at these voltages, and the sodium current inactivates almost completely within $10 \mathrm{msec}$, so there should be little cross-contamination of the $I_{\mathrm{Na}}$ and $I_{\mathrm{K}}$ measurements.

(Hess et al., 1984; Lacerda and Brown, 1989) and sensory neurons (Aosaki and Kasai, 1989).

The potency of DHP antagonists is more difficult to evaluate due to the voltage or state dependence of DHP antagonist action (Bean, 1984; Bean et al., 1986). Estimates of the dissociation constant of DHP antagonists for closed states of cardiac calcium channels range from 0.7 to $7 \mu \mathbf{M}$; at depolarized voltages, the $\mathrm{EC}_{50}$ is $<1 \mathrm{nM}$ (Bean, 1984; Sanguinetti and Kass, 1984; see also Cohen and McCarthy, 1987, for $\mathrm{GH}_{3}$ cells). Resting block appears to be stronger $\left(\mathrm{EC}_{50} 3-200 \mathrm{nM}\right.$ ) for calcium channels in smooth muscle (Bean et al., 1986; Yatani et al., 1987; Hering et al., 1988; McCarthy and Cohen, 1989; Nelson and Worley, 1989). The $\mathrm{EC}_{50}$ of $300 \mathrm{~nm}$ for blockade of the Bay K 8644 effect by nifedipine, from a holding potential of $-80 \mathrm{mV}$, is thus in the expected range. The $\mathrm{EC}_{50}$ measured in that way might be affected by interactions between nifedipine and Bay K 8644 , and the effect could be in either direction. If DHP agonists and antagonists interact competitively, the potency of nifedipine would be underestimated (Nelson and Worley, 1989). Alternatively, DHP agonists, by promoting the open state of the channel, could facilitate DHP antagonist binding. Cooperative interactions of DHP agonists and antagonists have sometimes been observed in binding studies (Kokubun et al., 1986). Despite such uncertainties, it is clear that the action of nifedipine is qualitatively similar to its effect on L-type calcium currents of cardiac muscle.

As expected for action on an L-channel, nifedipine was more potent from a depolarized holding potential, $-50 \mathrm{mV}$ (Figs. 7, 8). Rundown makes the $\mathrm{EC}_{50}$ difficult to estimate, but it is probably $<100$ nM. DHP antagonists (Fig. 8) and agonists (data not shown) had larger fractional effects following pretreatment with $\omega$-conotoxin, as expected for a selective but incomplete blockade of N-current (Plummer et al., 1989). Under conditions where the DHP antagonist effect was large, there was still no obvious difference between the activation kinetics of DHP-sensitive and DHP-resistant components of the calcium current (Fig. 8B), consistent with the observation of tail currents well fit by a single-exponential process (Swandulla and Armstrong, 1988; Jones and Marks, 1989a).

Two observations suggest that high concentrations of DHPs have a weak blocking action on the $\mathrm{N}$-current. The stronger evidence is actually for DHP agonists (Fig. $2 B$ ). The complex action of $(+) 202-791$ on the peak current could have been explained as a mixture of agonist and antagonist properties on L-current, which has been observed even for "pure" agonist isomers (Kass, 1987), except that the 2 effects show differential rundown. The agonist effect (on peak current or on the slow tail currents) was relatively weaker after long periods of whole-cell recording. This can be most easily explained if the antagonist effect is on $\mathrm{N}$-current, with $\mathrm{N}$-current showing less rundown than L-current. If all of the effects of $(+) 202-791$ are on L-current, the L-current remaining after long periods of dialysis must have selectively lost agonist sensitivity, which seems less plausible. It is more difficult to demonstrate a clear effect of DHP antagonists on $\mathrm{N}$-current, but $10 \mu \mathrm{M}$ nifedipine has a stronger blocking action on the control current than does $1 \mu \mathrm{M}$ nifedipine (Figs. 4,6), despite nearly full block of the DHP agonist-induced current by $1 \mu \mathrm{M}$ nifedipine. The simplest interpretation is that $10 \mu \mathrm{M}$ nifedipine has a weak, nonspecific blocking action on $\mathrm{N}$-current.

A slight blockade of $\mathrm{N}$-current by micromolar concentrations of DHPs should not be surprising. At such concentrations, DHPs are known to have effects on other currents, including sodium (Yatani and Brown, 1985), potassium (Nerbonne and Gurney, 1987), and T-type calcium (Akaike et al., 1989) currents. In fact, DHPs appear to block potassium currents more strongly than they block the N-current (Fig. 9, Table 1). The high lipid solubility of DHPs would produce extremely high concentrations in membranes, which could easily have nonselective effects. Clearly, effects of DHPs at micromolar concentrations must be interpreted with extreme caution.

Aosaki and Kasai (1989) recently reported similar results for DHP actions on calcium currents of chick sensory neurons. However, they found no effect of nifedipine (up to $10 \mu \mathrm{M}$ ) on $\mathrm{N}$-current. They also concluded that the $\omega$-conotoxin-resistant current was predominantly a DHP-sensitive L-current, even though it showed a slow $(\sim 10 \mathrm{sec})$ inactivation process upon changes in holding potential. Inactivation at $-40 \mathrm{mV}$ has been considered a hallmark of N-current (Fox et al., 1987a), but L-current in cardiac cells inactivates slowly and reversibly at a holding potential of $-40 \mathrm{mV}$ (Schouten and Morad, 1989). For sympathetic neurons, Plummer et al. (1989) concluded that most of the $\omega$-conotoxin-resistant current was $\mathrm{N}$-current. The current following $\omega$-conotoxin was clearly relatively enriched in L-current (Fig. 8), especially from relatively positive holding potentials, but most of the current from $-80 \mathrm{mV}$ was still DHPresistant.

It now seems indisputable that distinct $\mathrm{L}$ - and $\mathrm{N}$-currents coexist in whole-cell recordings from sympathetic neurons. However, the $\mathrm{N}$-current is kinetically different from that originally described in sensory neurons, and the contribution of L-current is quantitatively minor (Jones and Marks, 1989b; Plummer et al., 1989). DHPs remain useful tools for separating L- and N-currents, but "side effects" and the voltage dependence of DHP action make this a nontrivial problem. In particular, it remains difficult to conclude that the contribution of $\mathrm{L}$-current to the whole-cell current can be determined by blockade with a particular concentration of DHP antagonist.

\section{References}

Adams PR, Brown DA, Constanti A (1982) M-currents and other potassium currents in bullfrog sympathetic neurones. J Physiol (Lond) 330:537-572. 
Akaike N, Kostyuk PG, Osipchuk YV (1989) Dihydropyridine-sensitive low-threshold calcium channels in isolated rat hypothalamic neurones. J Physiol (Lond) 412:181-195.

Aosaki T, Kasai H (1989) Characterization of two kinds of highvoltage-activated $\mathrm{Ca}$-channel currents in chick sensory neurons. Differential sensitivity to dihydropyridines and $\omega$-conotoxin GVIA. Pfluegers Arch 414:150-156.

Bean BP (1984) Nitrendipine block of cardiac calcium channels: highaffinity binding to the inactivated state. Proc Natl Acad Sci USA 81: 6388-6392.

Bean BP (1989) Classes of calcium channels in vertebrate cells. Annu Rev Physiol 51:367-384.

Bean BP, Sturek M, Puga A, Hermsmeyer K (1986) Calcium channels in muscle cells isolated from rat mesenteric arteries: modulation by dihydropyridine drugs. Circ Res 59:229-235.

Caffrey JM, Josephson IR, Brown AM (1986) Calcium channels of amphibian stomach and mammalian aorta smooth muscle cells. Biophys J 49:1237-1242.

Cohen CJ, McCarthy RT (1987) Nimodipine block of calcium channels in rat anterior pituitary cells. J Physiol (I ond) 387:195-225.

Fox AP, Nowycky MC, Tsien RW (1987a) Kinetic and pharmacological properties distinguishing three types of calcium currents in chick sensory neurones. J Physiol (Lond) 394:149-172.

Fox AP, Nowycky MC, Tsien RW (1987b) Single-channel recordings of three types of calcium channels in chick sensory neurones. J Physiol (Lond) 394:173-200.

Hering S, Beech DJ, Bolton TB, Lim SP (1988) Action of nifedipine or BAY K8644 is dependent on calcium channel state in single smooth muscle cells from rabbit ear artery. Pfluegers Arch 411:590-592.

Hess P, Lansman JB, Tsien RW (1984) Different modes of Ca channel gating behaviour favoured by dihydropyridine $\mathrm{Ca}$ agonists and antagonists. Nature 311:538-544.

Hirning LD, Fox AP, McCleskey EW, Olivera BM, Thayer SA, Miller $\mathrm{RJ}$, Tsien RW (1988) Dominant role of $\mathrm{N}$-type $\mathrm{Ca}^{2+}$ channels in evoked release of norepinephrine from sympathetic neurons. Science 239:57-61.

Jones SW, Jacobs LS (1989) Bay K 8644 is highly potent, but has small maximal effects, on calcium currents of isolated frog sympathetic neurons. Soc Neurosci Abstr 15:651.

Jones SW, Marks TN (1989a) Calcium currents in bullfrog sympathetic neurons. I. Activation kinetics and pharmacology. J Gen Physiol 94:151-167.

Jones SW, Marks TN (1989b) Calcium currents in bullfrog sympathetic neurons. II. Inactivation. J Gen Physiol 94:169-182.

Kass RS (1987) Voltage-dependent modulation of cardiac calcium channel current by optical isomers of Bay K 8644: implications for channel gating. Circ Res (Suppl I) 61:I1-I5.

Kokubun S, Prod'hom B, Becker C, Porzig H, Reuter H (1986) Studies on $\mathrm{Ca}$ channels in intact cardiac cells: voltage-dependent effects and cooperative interactions of dihydropyridine enantiomers. Mol Pharmacol 30:571-584.
Lacerda AE, Brown AM (1989) Nonmodal gating of cardiac calcium channels as revealed by dihydropyridines. J Gen Physiol 93:12431273.

Lipscombe D, Madison DV, Poenie M, Reuter H, Tsien RY, Tsien RW (1988) Spatial distribution of calcium channels and cytosolic calcium transients in growth cones and cell bodies of sympathetic neurons. Proc Natl Acad Sci USA 85:2398-2402.

McCarthy RT, Cohen CJ (1989) Nimodipine block of calcium channels in rat vascular smooth muscle cell lines. Exceptionally highaffinity binding in A7r5 and A10 cells. J Gen Physiol 94:669-692.

McCleskey EW, Fox AP, Feldman D, Tsien RW (1986) Different types of calcium channels. $J$ Exp Biol 124:177-190.

Nelson MT, Worley JF (1989) Dihydropyridine inhibition of single calcium channels and contraction in rabbit mesenteric artery depends on voltage. J Physiol (Lond) 412:65-91.

Nerbonne JM, Gurney AM (1987) Blockade of $\mathrm{Ca}^{2+}$ and $\mathrm{K}^{+}$currents in bag cell neurons of Aplysia californica by dihydropyridine $\mathrm{Ca}^{2+}$ antagonists. J Neurosci 7:882-893.

Nowycky MC, Fox AP, Tsien RW (1985) Three types of neuronal calcium channels with different calcium agonist sensitivity. Nature 316:440-443.

Perney TM, Hirning LD, Leeman SE, Miller RJ (1986) Multiple calcium channels mediate neurotransmitter release from peripheral neurons. Proc Natl Acad Sci USA 83:6656-6659.

Plummer MR, Logothetis DE, Hess P (1989) Elementary properties and pharmacological sensitivities of calcium channels in mammalian peripheral neurons. Neuron 2:1453-1463.

Sanguinetti MC, Kass RS (1984) Voltage-dependent block of calcium channel current in the calf cardiac Purkinje fiber by dihydropyridine calcium channel antagonists. Circ Res 55:336-348.

Sanguinetti MC, Krafte DS, Kass RS (1986) Voltage-dependent modulation of Ca channel current in heart cells by Bay K8644. J Gen Physiol 88:369-392.

Schouten VJA, Morad M (1989) Regulation of $\mathrm{Ca}^{2+}$ current in frog ventricular myocytes by the holding potential, c-AMP and frequency. Pfluegers Arch 415:1-11.

Swandulla D, Armstrong CM (1988) Fast-dcactivating calcium channels in chick sensory neurons. J Gen Physiol 92:197-218.

Taylor WR (1988) Two-suction-electrode voltage-clamp analysis of the sustained calcium current in cat sensory neurones. J Physiol (Lond) 407:405-432.

Tsien RW, Lipscombe D, Madison DV, Bley KR, Fox AP (1988) Multiple types of neuronal calcium channels and their selective modulation. Trends Neurosci 11:431-438.

Yatani A, Brown AM (1985) The calcium channel blocker nitrendipine blocks sodium channels in neonatal rat cardiac myocytes. Circ Res 56:868-875.

Yatani A, Seidel CL, Allen J, Brown AM (1987) Whole-cell and singlechannel calcium currents of isolated smooth muscle cells from saphenous vein. Circ Res 60:523-533. 